\title{
Oxidation of Volatile Nitrogen Compounds during Combustion in Circulating Fluidized Bed Boilers
}

\author{
Lars-Erik Åmand* and Bo Leckner \\ Department of Energy Conversion, Chalmers University of Technology, S-412 96 Göteborg, \\ Sweden
}

Received May 8, 1991. Revised Manuscript Received July 29, 1991

In circulating fluidized bed boilers, the volatile nitrogen species of the fuel are mostly oxidized to NO. This is shown in a test program where the effect of batch supply of fuel on the NO emission has been investigated in two different commercial-type fluidized bed boilers. Measurements of gas concentration profiles of $\mathrm{CO}, \mathrm{NO}, \mathrm{HCN}, \mathrm{NH}_{3}$, and $\mathrm{C}_{1}$ to $\mathrm{C}_{3}$ hydrocarbons in the boilers support the conclusions from the batch supply tests.

\section{Introduction}

Fluidized bed combustion (FBC) is a convenient way of burning solid fuels in order to achieve low emissions of NO and $\mathrm{SO}_{2}$. The reason for this is the combustion temperatures of $800-900^{\circ} \mathrm{C}$ which are low in comparison with the temperatures of pulverized coal combustion, $1000-1600^{\circ} \mathrm{C}$. The low temperatures in FBC prevent thermal NO formation and promote NO reducing reactions during combustion. The temperature range is also suitable for sulfur capture by limestone addition.

The circulating type of FB boiler (CFB boiler) takes even better advantage of these aspects ${ }^{1}$ and interest has gradually been focussed on this type of boiler. However, the advantage of the lower emissions of $\mathrm{NO}$ and $\mathrm{SO}_{2}$ has lately been found to be offset by high emissions of $\mathrm{N}_{2} \mathrm{O}$ as a consequence of the temperature level. High emission of $\mathrm{N}_{2} \mathrm{O}$ has been reported for $\mathrm{FB}$ boilers ${ }^{2}$ but not for other combustion techniques. ${ }^{3} \quad \mathrm{~N}_{2} \mathrm{O}$ is one of the greenhouse gases, and it also contributes to the ozone depletion in the stratosphere. ${ }^{4}$

This paper is a continuation of an $\mathrm{NO}_{x}$ emission project previously published. ${ }^{2,5-7}$ Characterization of $\mathrm{N}_{2} \mathrm{O}$ is included in the $\mathrm{NO}_{x}$ emission project but, for convenience, results related to $\mathrm{N}_{2} \mathrm{O}$ are reported separately. ${ }^{8}$ In refs 5,6 , and 7 it has been stressed that, in CFB boilers, reactions involving NO reduction on char surfaces are favored more than NO reduction reactions involving ammonia $\left(\mathrm{NH}_{3}\right)$ or other amines $\left(\mathrm{NH}_{i}\right)$. This should be compared with the situation in the stationary (bubbling)

(1) Leckner, B.; Ȧmand, L-E. In Ninth International Conference on Fluidized Bed Combustion; Mustonen, J. P., Ed.; The American Society of Mechanical Engineers: New York, 1987; $p 891$.

(2) Amand, L-E.; Andersson, S. In Tenth International Conference on Fluidized Bed Combustion; Manaker, A. M. Ed.; The American Society of Mechanical Engineers: New York, 1989; p 49.

(3) Linak, W. P.; McSorley, J. A.; Hall, R. E.; Ryan, J. V.; Srivastavan, R. K.; Wendt, J. O. L.; Mereb, J. B. J. Geophys. Res. 1990, 95, 7533. (4) Levine, J. "Nitrous Oxide: Sources and Impact on Atmospheric Chemistry and Global Climate"; European Workshop on $\mathrm{N}_{2} \mathrm{O}$, LNE. TI/EPA/IFP, Lisboa, Portugal, June 1990.

(5) Amand, L-E.; Leckner, B. Combust. Flame 1991, 84, 181.

(6) Amand, L-E.; Leckner, B. Proceedings of the Twenty-Third Symposium (International) on Combustion; The Combustion Institute, Pittsburg, 1990.

(7) Johnsson, J.-E.; Amand, L-E.; Leckner, N. In Circulating Fluidized Bed Technology III; Basu, P., Horio, M., Hasatani, M., Eds.; Pergamon Press: Oxford, U.K., 1991; p 405

(8) Amand, L-E.; Leckner, B.; Andersson, S. Formation of $\mathrm{N}_{2} \mathrm{O}$ in Circulating Fluidized Bed Boilers. Energy Fuels, following paper in this issue.
Table I. The Fuels

\begin{tabular}{|c|c|c|c|c|c|c|}
\hline & \multicolumn{4}{|c|}{ bituminous } & \multirow[b]{2}{*}{$\begin{array}{l}\text { petroleum } \\
\text { coke }\end{array}$} & \multirow[b]{2}{*}{$\begin{array}{l}\text { anthra- } \\
\text { cite }\end{array}$} \\
\hline & $\begin{array}{l}\text { coal } \\
\text { no. } 1\end{array}$ & $\begin{array}{l}\text { coal } \\
\text { no. } 2\end{array}$ & $\begin{array}{l}\text { coal } \\
\text { no. } 3\end{array}$ & $\begin{array}{c}\text { coal } \\
\text { no. } 4\end{array}$ & & \\
\hline $\begin{array}{l}\text { size (mass mean), } \\
\text { mm }\end{array}$ & 6.5 & 2.5 & 16 & 11 & 14 & 1.9 \\
\hline $\begin{array}{l}\%<1 \mathrm{~mm} \\
\text { volatiles, } \% \text { maf }\end{array}$ & $\begin{array}{l}11 \\
35.5\end{array}$ & $\begin{array}{l}35 \\
30.3\end{array}$ & $\begin{array}{l}0 \\
30.3\end{array}$ & $\begin{array}{l}13 \\
30.0\end{array}$ & $\begin{array}{l}0 \\
14.3\end{array}$ & $\begin{array}{l}50 \\
11.1\end{array}$ \\
\hline $\begin{array}{l}\text { proxim anal, \% as } \\
\text { delivrd }\end{array}$ & & & & & & \\
\hline combustibles & 87 & 82.0 & 82.0 & 78.0 & 95.2 & 81 \\
\hline ash & 7 & 9.0 & 9.2 & 12.5 & 3.10 & 16.5 \\
\hline moisture & 6 & 9.0 & 8.8 & 9.5 & 1.7 & 2.5 \\
\hline ultim anal, $\%$ maf & & & & & & \\
\hline $\mathrm{C}$ & 82.7 & 85.3 & 85.3 & 84 & 89.8 & 92.1 \\
\hline $\mathrm{H}$ & 5.2 & 4.5 & 4.5 & 5 & 4.1 & 1.6 \\
\hline 0 & 8.8 & 7.4 & 7.4 & 9 & 2.7 & 2.6 \\
\hline $\mathrm{s}$ & 1.6 & 1.1 & 1.1 & 0.5 & 2.0 & 2.3 \\
\hline $\mathrm{N}$ & 1.7 & 1.7 & 1.7 & 1.9 & 1.4 & 1.4 \\
\hline heating value, & 33.1 & 33.2 & 33.2 & 33.1 & 35.4 & 32.0 \\
\hline $\begin{array}{l}\text { lower, } \\
\mathrm{MJ} / \mathrm{kg} \text { maf }\end{array}$ & & & & & & \\
\hline
\end{tabular}

fluidized bed (SFB) boiler, where the char is concentrated in the dense bed at the bottom of the combustion chamber, and a freeboard with low particle density plays a role which is different from that of the upper part of the combustion chamber of the CFB-type of FB boiler. In other words, it is possible for the homogeneous reduction of $\mathrm{NO}$ by $\mathrm{NH}_{3}$ (or other amines) to take place in the freeboard of the SFB boiler but not in a CFB boiler. In order to prove that this reaction is not of significance for the NO reduction in CFB boilers, a test program has been carried out. The tests combine measurements and comparative studies of the effect of batch supply of fuel in two different commercial-type CFB boilers. In addition, the gas-concentration profiles measured in the combustion chambers of the two boilers are valuable for a general characterization of the NO reduction in CFB boilers. These profiles show that the NO-char reaction plays a dominant role. Although the importance of the char and $\mathrm{CO}$ for the NO reduction during FB combustion has already been discussed, ${ }^{9-11}$ and the references mentioned are referred to in most publi-

(9) Pereira, F. J.; Beër, J. M.; Gibbs, B.; Hedley, A. B. Proceedings of the Fifteenth Symposium (International) on Combustion; The Combustion Institute: Pittsburgh, 1974; $p 1149$.

(10) Gibbs, B. M.; Pereira, F. J.; Beêr, J. M. Proceedings of the Sixteenth Symposium (International) on Combustion; The Combustion Institute: Pittsburgh, 1977; $p 461$.

(11) Furusawa. T.; Honda, T.; Takuno, J.; Kunii, D. J. Chem. Eng. Jpn. 1978, 11, 377. 


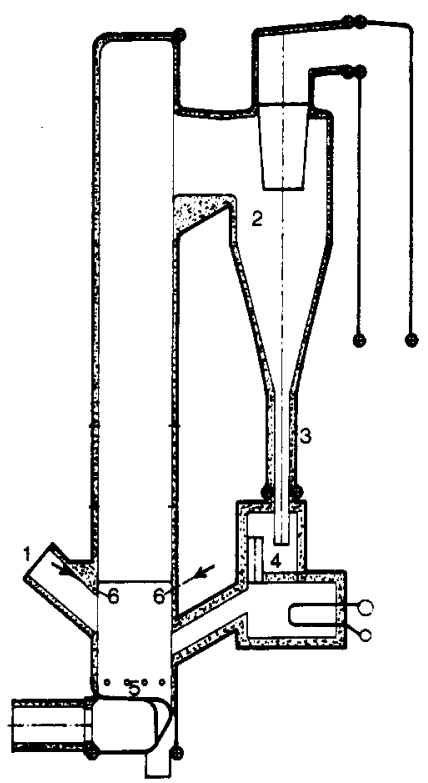

Figure 1. The 12-MW $\mathrm{MW}_{\text {th }}$ CFB boiler at Chalmers University of Technology. (1) Fuel feed chute, (2) cyclone, (3) particle return leg, (4) particle seal, (5) bottom plate, (6) secondary air inlet.

cations concerning NO emissions from FB boilers, there are still new aspects of this reaction that can be seen in the test program presented below. These new aspects confirm the observations made previously,6 that (1) the volatile nitrogen species are mostly oxidized to NO in a CFB boiler using bituminous coal or fuels of higher rank; and (2) the $\mathrm{CO}$ level is important for the NO reduction on char surfaces.

\section{Experimental Section}

The Boilers. The tests were run in two CFB boilers, one 8-MW boiler designed and built by Götaverken Energy in 1981 at Cityvarvet, and one $12-\mathrm{MW}_{\mathrm{th}}$ boiler built by Generator Industri AB in 1989 at Chalmers University of Technology (Figure 1). Both boilers are built in the form of commercial boilers, with the combustion chamber made up of membrane tube walls, and the gross features of the boilers are similar. The height of the combustion chamber is $7.8 \mathrm{~m}$ and the cross section is about $1.8 \mathrm{~m}^{2}$ for the 8-MW boiler. Corresponding data for the 12-MW unit are $13.5 \mathrm{~m}$ and $2.9 \mathrm{~m}^{2}$. Fuel is fed to the bottom of the combustion chamber through a fuel screw in the 8-MW boiler, while a fuel chute (1) is used in the 12-MW boiler. In both boilers bed material is separated from the gases in the hot cyclone (2) and passed back to the combustion chamber through the return leg (3) and the particle seal (4). Primary air is introduced through air nozzles in the bottom plate (5) and secondary air can be introduced through several secondary air registers located along the combustion chamber. The lowest level (6) is located at $2.2 \mathrm{~m}$ in the 12-MW boiler while the lowest secondary air level in the 8-MW boiler is located only $1 \mathrm{~m}$ above the bottom plate. Both boilers are equipped with data-acquisition systems and on-line gas analyzers for sampling of data needed in the research program.

The Fuels. In both boilers high-volatile bituminous coals have been used as fuel, having the properties shown in Table I. In the 8-MW boiler anthracite and petroleum coke were also employed in some tests.

The Tests. A reference case was defined where the bottom bed temperature was kept at $850^{\circ} \mathrm{C}$, the primary air stoichiometry was around 0.75 , and the excess air ratio 1.2 . The fluidizing velocities were between 4 and $6 \mathrm{~m} / \mathrm{s}$. While the boiler was operated according to the conditions of this reference case, batches of fuels of different volatile content were dropped into the combustion chamber of the 8-MW boiler and the effect on the $\mathrm{O}_{2}$ and NO emissions was followed during the burnout period. In the 12-MW boiler similar tests were carried out; however, only one type of fuel was used as a batch fuel. The fuel particle size and amounts of fuel in the batches were varied instead.
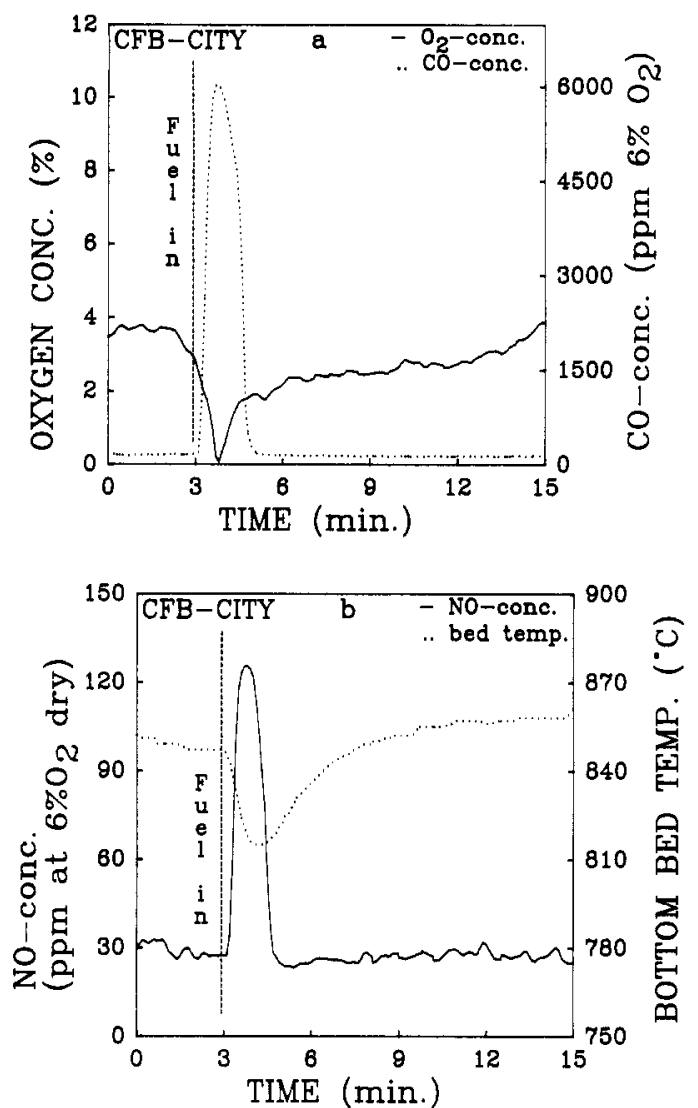

Figure 2. Batch supply of bituminous coal no. 3. Effect on $\mathrm{O}_{2}-\mathrm{CO}-\mathrm{NO}$ concentrations and bed temperature during the burnout period. Batch size/fuel flow $=7.3$. Reference fuel: bituminous coal no. 2. 8-MW CFB boiler.

In the reference case, concentration profiles of $\mathrm{NO}$ and $\mathrm{CO}$ in the combustion chambers of both boilers were measured. In the 12-MW boiler the profiles of $\mathrm{NH}_{3}$ and $\mathrm{HCN}$ together with $\mathrm{C}_{1}$ to $\mathrm{C}_{3}$ hydrocarbons were also included.

The Gas Sampling Probes. The concentration profiles were taken inside the combustion chambers by means of gas sampling probes. Gas was withdrawn through a cooled filter located at the top of the probe. The particle-free gas was then sent to on-line analysis for $\mathrm{O}_{2}, \mathrm{CO}$, and NO. In the 12-MW CFBB boiler also the $\mathrm{HCN}$ and $\mathrm{NH}_{3}$ profile and the concentrations of $\mathrm{C}_{1}$ to $\mathrm{C}_{3}$ hydrocarbons were measured. The $\mathrm{NH}_{3}$ and $\mathrm{HCN}$ concentrations were determined by trapping the gases in wash bottles containing a diluted acidic water solution for $\mathrm{NH}_{3}$ and a basic water solution for HCN. The analysis could then be carried out by means of ion-selective electrodes for $\mathrm{NH}_{3}$ and argentometry (Liebig-Deniges method) for HCN. After drying, gas from the probes was also collected in Tedlar bags for further analyses for $\mathrm{N}_{2} \mathrm{O}$ and hydrocarbons on a gas chromatograph equipped with an electroncapture detector (for $\mathrm{N}_{2} \mathrm{O}$ ) and a flame-ionization detector (for hydrocarbons).

\section{Results}

Burnout of Batches of Fuels in the 8-MW Boiler (CFB Cityvarvet). In the test series involving batches of fuel the 8-MW boiler was operated under the reference conditions with the low-sulfur coal (coal no. 2); see Table I. At stable operating conditions a batch was dropped into the fuel feed screw corresponding to an increase of the fuel feed rate by a factor of about 7-8. Not more than $30 \mathrm{~s}$ elapsed before the entire batch of fuel was fed into the combustion chamber. Three fuels (coal no. 3, petroleum coke, and anthracite), each with a different content of volatiles, were used as batch fuels. The effect of the batch fuel on the concentrations of oxygen, $\mathrm{CO}$, and $\mathrm{NO}$ in the stack, as well as the bottom-bed temperature, was followed 

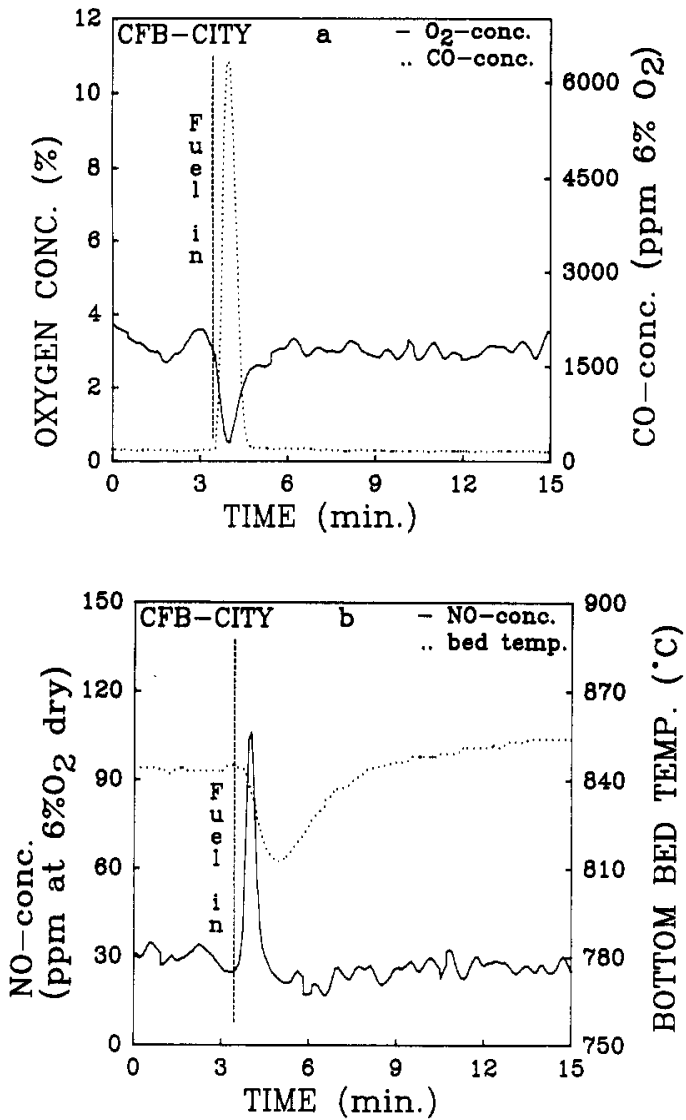

Figure 3. Batch supply of petroleum coke. Effect on $\mathrm{O}_{2}-\mathrm{CO}-\mathrm{NO}$ concentrations and bed temperature during the burnout period. Batch size/fuel flow $=8.5$. Reference fuel: bituminous coal no. 2. 8-MW CFB boiler.

during the burnout period and is shown for the three tests in Figures 2, 3 and 4. For all three fuels the effect is more or less the same. There is a decrease in the oxygen concentration and bed temperature and an increase in the $\mathrm{CO}$ and NO concentrations during the volatile release period. Higher volatile content of the fuel leads to larger peaks in $\mathrm{CO}$ and $\mathrm{NO}$.

Burnout of Batches of Fuel in the 12-MW Boiler (CFB Chalmers). The tests using batches of fuel were carried out in a somewhat different way in the $12-\mathrm{MW}$ boiler. The operating conditions were those of the reference case; however, instead of using batches of fuels of different volatile contents, the same fuel was fed, and the size and amount of fuel were varied. The results of two tests with the same amount of batch fuel are shown in Figure 5. The coarse fuel was tested first. This fraction of the fuel contained only pieces between 15 and $40 \mathrm{~mm}$ (mass mean size of $22 \mathrm{~mm}$ ). The fine fraction was removed and was further crushed down to a mean size (mass based) of only $0.25 \mathrm{~mm}$. In order to avoid as large peaks in CO as were recorded in the 8-MW boiler, the batch size was only about one-third of the one used in the 8-MW boiler. The effect on the oxygen, $\mathrm{CO}$, and $\mathrm{NO}$ concentrations was different in the 12-MW boiler. The slow and prolonged devolatilization, which was caused by the coarse batch fuel, did not influence the bed temperature at all. The oxygen concentration dropped only a little, and a long, delayed recovery period followed. No CO peak was found and the NO concentration dropped and did not increase as it did in the 8-MW boiler. On the other hand, the rapid devolatilization of the crushed fuel increased the bed temperature and caused the oxygen concentration to drop quickly, after which it returned to the original concentration very fast. There is also a large CO peak, but still no increase
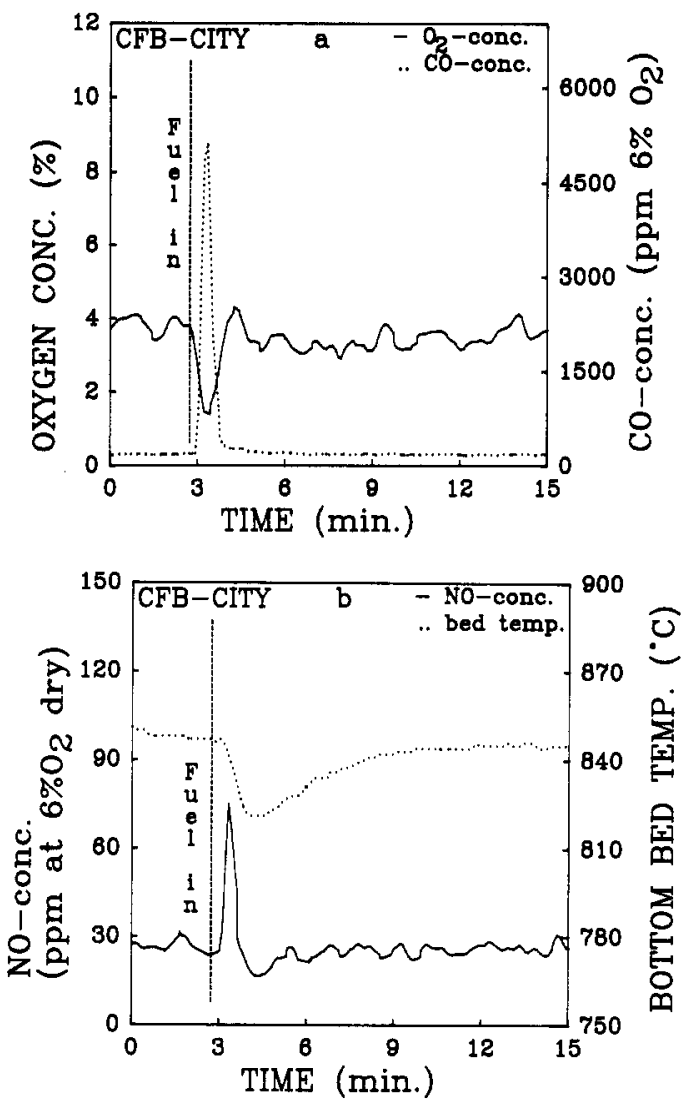

Figure 4. Batch supply of anthracite. Effect on $\mathrm{O}_{2}-\mathrm{CO}-\mathrm{NO}$ concentration during the burnout period. Batch size/fuel flow =6.5. Reference fuel: bituminous coal no. 2. 8-MW CFB boiler.

of the NO concentration. In the last test, shown in Figure 6 , the batch size was therefore made 3.5 times larger. Mixed size fuel was used, of a size between 1 and $25 \mathrm{~mm}$. This time the exit oxygen concentration dropped to zero and a long, slow recovery period of $25 \mathrm{~min}$ was recorded. The bed temperature decreased a little in the beginning, after which a large and slow increase took place. The CO peak was tremendous and could not be recorded completely, since a lower range on the $\mathrm{CO}$ analyzer was used by mistake. However, the $\mathrm{CO}$ disappeared as soon as the oxygen concentration started to increase again. The effect of the large batch of fuel on the NO emission is interesting. This time there was a certain increase of the NO concentration in the stack, but the NO decreased again as soon as the $\mathrm{CO}$ concentration started to decrease. Again there was no recording of an NO peak similar to those seen in the 8-MW boiler.

Gas Concentration Profiles in the Combustion Chambers. The results of the measurement of the gas concentration profiles are found in Figures 7-10. The vertical profiles were taken in the center from bottom to exit of the combustion chambers and include also measurements in the cyclone outlet and stack. In the 12-MW boiler, measurements of horizontal profiles were carried out at a few locations for some of the gas components as well. The staged air supply causes concentration gradients in the horizontal direction of the combustion chamber. This is a consequence of the size of the boiler rather than an effect of an uneven distribution of the secondary air between the nozzles. Problems with incomplete penetration of secondary air are always present in the evaluation of data from larger commercial boilers and the data presented below are representative for this class of experimental facilities. Further discussion of these problems together with a more complete presentation of all profiles 

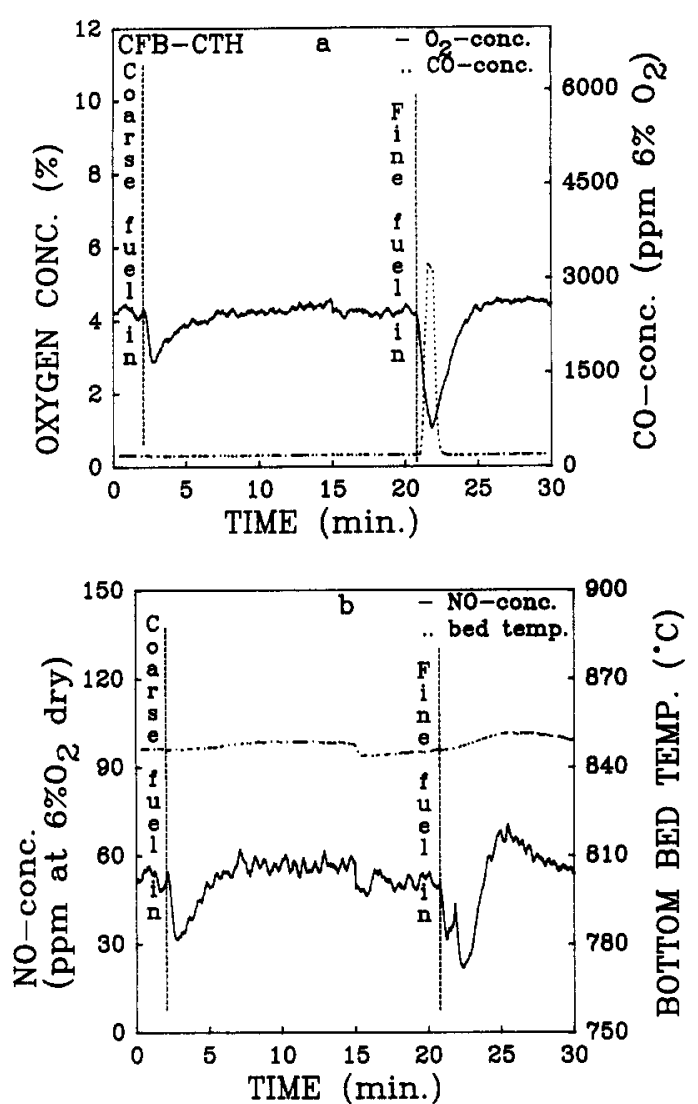

Figure 5. Batch supplies of equal amounts of bituminous coal no. 4 of coarse and fine size. Effect on $\mathrm{O}_{2}-\mathrm{CO}-\mathrm{NO}$ concentrations and bed temperature. Reference fuel: bituminous coal no. 4 . Batch size $/$ fuel flow $=2.3$. 12-MW CFB boiler.
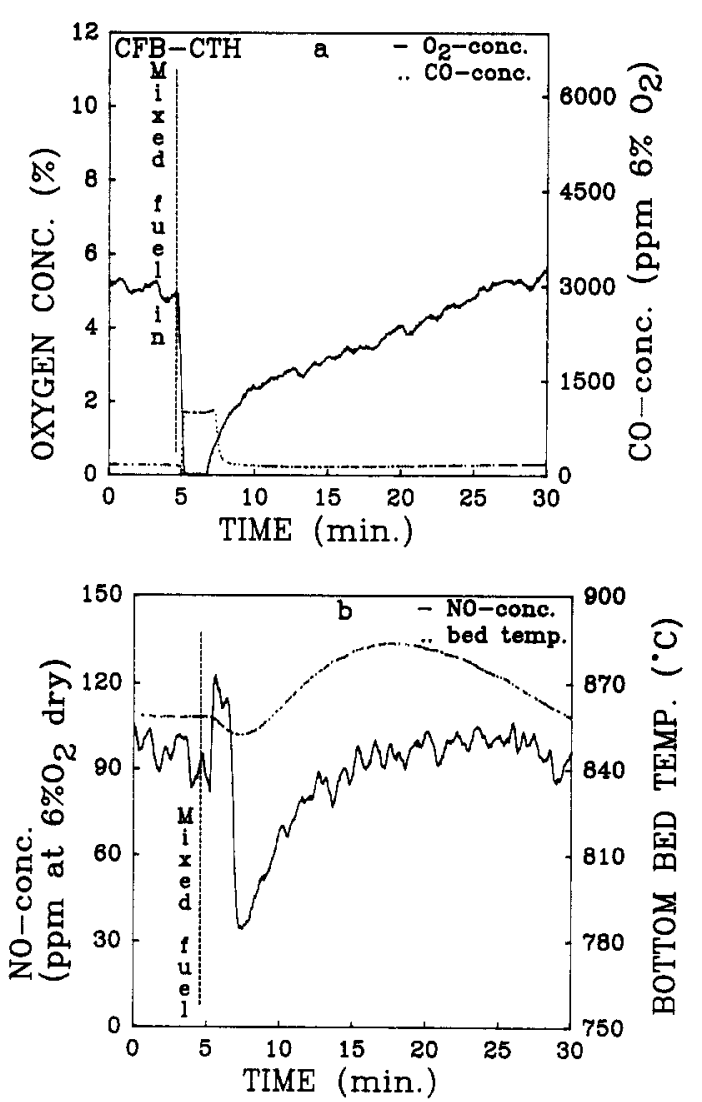

Figure 6. Large batch supply of bituminous coal no. 4. Effect on $\mathrm{O}_{2}-\mathrm{CO}-\mathrm{NO}$ concentrations and bed temperature. Batch supply/fuel flow $=8.1$. Reference fuel: bituminous coal no. 3 . 12-MW CFB boiler.

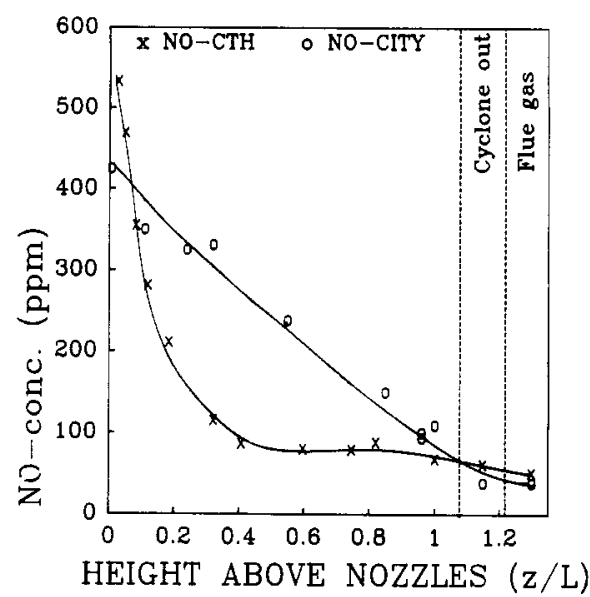

Figure 7. Comparison of the NO profiles in combustion chambers of the 8-MW and 12-MW CFB boilers. Operating conditions: reference case. Fuel in 8-MW boiler: bituminous coal no. 1. Fuel in 12-MW boiler: bituminous coal no. 4 .

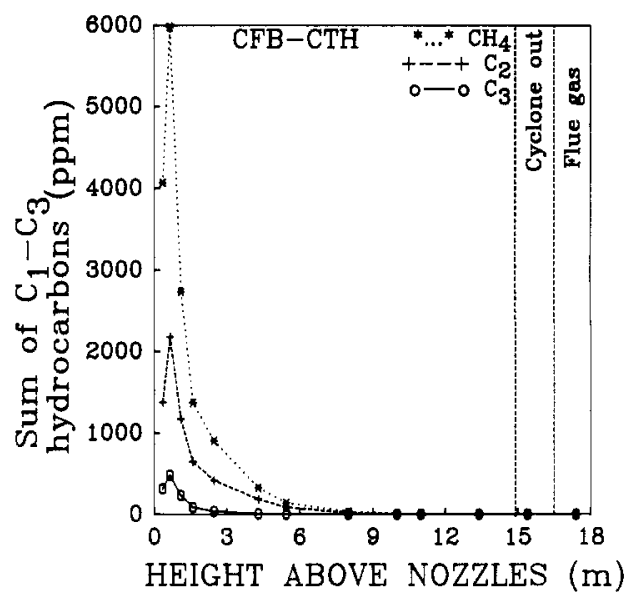

Figure 8. $C_{1}$ to $C_{3}$ profiles in the center of the combustion chamber of the 12-MW CFB boiler. Operating conditions: reference case. Fuel, bituminous coal no. 4.

taken in the 12-MW boiler is given by Amand et al. ${ }^{8}$

In Figure 7 comparison of the NO profiles from the two boilers is shown. In both cases there are high levels of NO at the bottom of the combustion chamber. The NO concentration decreases higher up in the combustion chamber. This decrease is partly an effect of dilution by secondary air and partly because of reduction of NO. The reduction of NO is almost complete at the exit, down to only $40 \mathrm{ppm}$ for the 12-MW boiler and $30 \mathrm{ppm}$ for the 8-MW boiler.

The concentration of $\mathrm{C}_{1}$ to $\mathrm{C}_{3}$ hydrocarbons measured only in the 12-MW boiler is plotted in Figure 8. The high levels of $\mathrm{CH}_{4}$ and the drastic drop in the concentration of the higher hydrocarbons $\mathrm{C}_{2}$ and $\mathrm{C}_{3}$ can be seen. For all three classes of hydrocarbons, there is a rapid evolution at the bottom of the combustion chamber similar to that of the nitrogen-containing constituent of the volatiles, $\mathrm{NH}_{3}$ and HCN (Figure 9). After the maximum concentration is reached at $0.65 \mathrm{~m}$ above the bottom plate, a rapid oxidation of the hydrocarbons takes place. As a matter of fact, the hydrocarbon profile shows that the major part of the volatiles is released close to the bottom of the combustion chamber (below $1 \mathrm{~m}$ ).

A comparison of the $\mathrm{CO}$ levels of the two boilers is shown in Figure 10. In the 8-MW boiler $\mathrm{CO}$ levels between 1 and $6 \%$ were measured in the combustion chamber, while only $0.05-2 \%$ were found in the $12-\mathrm{MW}$ boiler. The reason for this large difference in $\mathrm{CO}$ level is probably due to the mixing of air and fuel. In the 8-MW boiler the secondary 


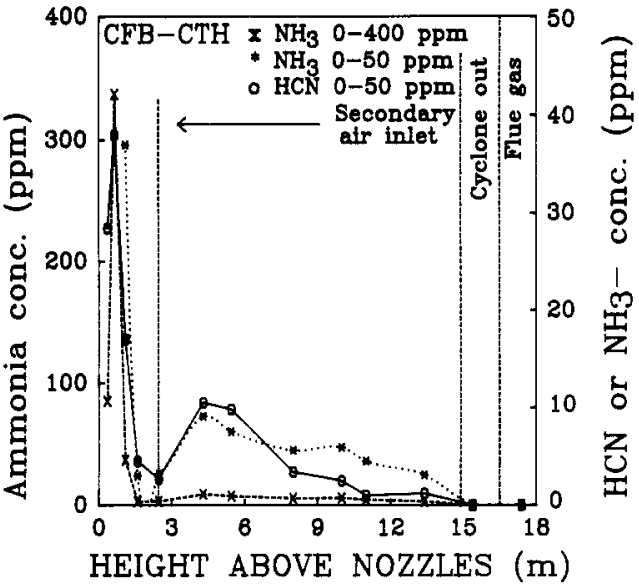

Figure 9. The $\mathrm{NH}_{3}$ and $\mathrm{HCN}$ profiles in the center of the combustion chamber of the 12-MW CFB boiler. The $\mathrm{NH}_{3}$ concentration is shown at $0-400 \mathrm{ppm}$ range on left axis and $0-50 \mathrm{ppm}$ range on right axis. Operating conditions: reference case. Fuel, bituminous coal no. 4 .

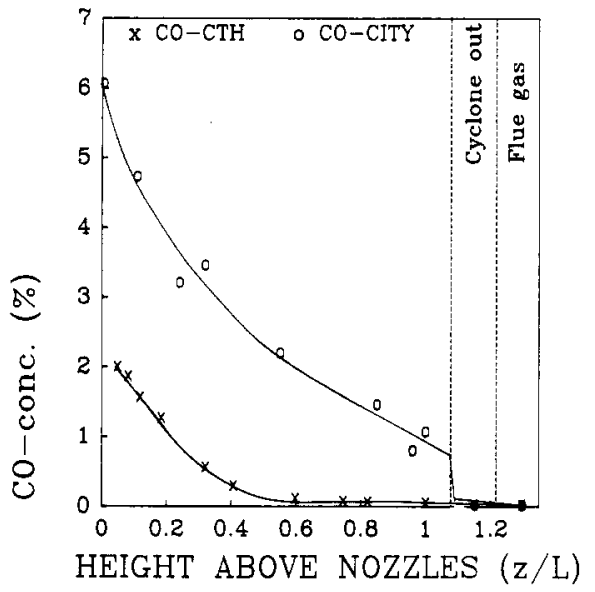

Figure 10. Comparison of the CO profiles in the combustion chambers of the 8-MW and 12-MW CFB boilers. Operating conditions: reference case. Fuel in 8-MW boiler: bituminous coal no. 1. Fuel in 12-MW boiler: bituminous coal no. 4 .

air was introduced at $1 \mathrm{~m}$, where the particle density is high, through poorly designed and worn air ports, while in the new 12-MW boiler the secondary air supply has been moved up to the $2.2-\mathrm{m}$ level where there are air ports of a new and better design. The difference in fuel supply of the boilers, described earlier, might also be of importance. The third difference of importance is, possibly, the location of the inlet of recycled char from the hot cyclone. The distribution of these large amounts of combustible matter might affect the oxygen concentration in the bottom zone of the combustion chamber.

\section{Interpretation of the Results}

The Effect of Batches of Fuel on NO Emissions in CFBs. Transient tests for which batches of fuel have been burnt under fluidized bed conditions have been reported in the literature. ${ }^{9,10}$ In these tests a small electrically heated bubbling bed laboratory unit was used (diameter $7.5 \mathrm{~cm}$ ). Batches of coal particles were dropped into this unit under various conditions and the NO concentrations were recorded. This technique was also used in the large CFB boilers in this study. However, the large-scale tests differed somewhat from the laboratory tests, since the batch fuel was thrown into the combustion chamber in addition to the normal fuel. The normal NO reduction was then disturbed by the large amounts of volatiles produced and the changes were followed through the burnout period.

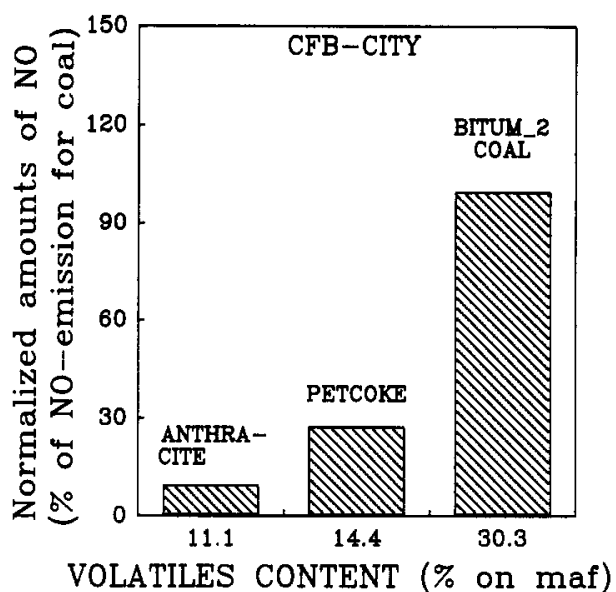

Figure 11. Normalization of the amounts of NO produced during the devolatilization period of the batch fuels in the 8-MW CFB boiler.

During the devolatilization period, two competing reactions prevail. The first one is caused by the large amounts of $\mathrm{CO}$ produced from the volatiles. This $\mathrm{CO}$ takes part in the NO reducing reaction on the surface of the char already present from the devolatilization of the normal fuel supplied at a constant feed rate. The second reaction is related to the large amounts of volatile nitrogen species which can be oxidized on the same char surface. The competing reaction that dominates can be identified by observing that there is an increase of the NO when oxidation of volatile nitrogen dominates, or a decrease of NO when the $\mathrm{CO}$ effect on NO-char reactions dominates. In the 8-MW CFB boiler the oxidation of volatile nitrogen dominates and in Figure 11 the results from Figures 2, 3, and 4 have been rewritten to show the normalized amounts of excess NO which are emitted during the NO peak caused by the batch fuel. For this normalization, attention has been paid to the different amounts of combustibles in each batch (due to different moisture and ash content) and the different nitrogen content. It is evident from Figure 11 that there is a strong correlation between the amount of volatile nitrogen in the fuel and the amount of NO produced during the NO peak.

The lack of an NO peak for the batch tests in the 12MW boiler (Figure 5) indicates the dominance of the CO concentration on the NO-char reactions. The test with the crushed coal aimed at increasing the release rate of volatiles. This strategy was expected to cause an NO peak. However, the batch size may have been too small, and the NO reduction on the char surface still dominates over the oxidation of volatile nitrogen species to NO. For that reason the batch size was increased 3.5 times (Figure 6). In this case an NO peak could be recorded.

In these tests, the effect of $\mathrm{CO}$ on the reduction of NO may have been influenced by a saturation of the reaction rate at high $\mathrm{CO}$ concentrations, and this may explain the different results in the two boilers. This assumption is based on the NO kinetics proposed by Chan and coworkers, ${ }^{12}$ who suggested that $C O$ reacts with chemisorbed oxygen on the carbon surface, thereby increasing the overall NO reduction rate on the char surface (Figure 12). However, the positive effect of $\mathrm{CO}$ can be expected only as long as the desorption of chemisorbed oxygen molecules is the rate-determining step. Therefore a state of saturation of the influence of $\mathrm{CO}$ can be expected at high $\mathrm{CO}$ levels, which is noticed in Figure 12. Since the CO levels

(12) Chan, L. K.; Sarofim, A. F.; Beêr, J. M. Combust. Flame 1983, 52 , 


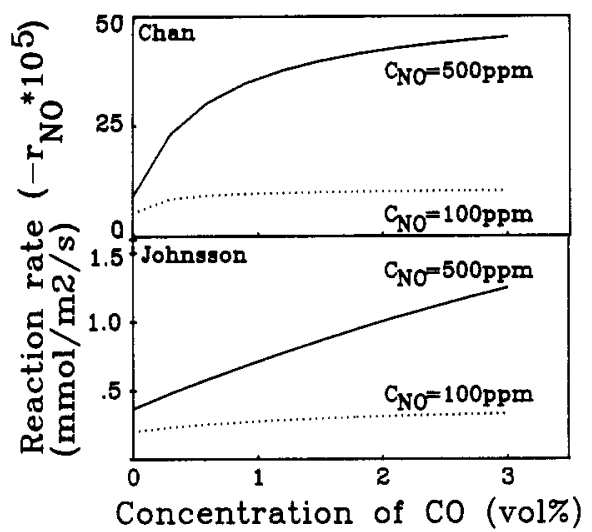

Figure 12. Comparison of the calculated reaction rates for the reduction of NO by CO with graphite ${ }^{12}$ and char from bituminous coal $^{13}$ as catalysts, at $800^{\circ} \mathrm{C}, 1.013$ bar. Rewritten from data of Johnsson. ${ }^{13}$

in the two boilers were different already before the batch tests (Figure 10), the influence of an additional amount of $\mathrm{CO}$ produced by the batch may have had different effects. In the 8-MW boiler where the background $\mathrm{CO}$ level was high, an addition to the $\mathrm{CO}$ concentration had less influence than in the $12-\mathrm{MW}$ boiler where the background concentration was lower. Even in the case of crushed coal (Figure 5) when the increased release rate of volatiles should have caused the $\mathrm{CO}$ concentration to approach saturation, the $\mathrm{CO}$ level seems to have been too low. The results of Chan and co-workers in Figure 12 are valid for graphite. An effort to reproduce these tests with char from a bituminous coal was made by Johnsson. ${ }^{13}$ As can be seen from Figure 12, where Johnsson's results are shown for comparison, the reaction rates are lower than those of Chan and co-workers and the saturation effect at higher $\mathrm{CO}$ concentrations is hardly noticeable. It is clear that further laboratory tests have to be done to ascertain to what extent Chan's results can be applied on other carbon forms.

The Gas Concentration Profiles. Concentration profiles of NO from the combustion chamber similar to those shown in Figure 7 have been measured in stationary fluidized bed boilers.9,10,14-16 These measurements have shown an increase of $\mathrm{NO}$ at the bottom of the bed, followed by a drop further up in the bed and in the freeboard. The general shape of the NO profile in fluidized bed boilers is taken as evidence of the importance of NO-reducing reactions such as the NO-char reaction and the homogeneous reduction of $\mathrm{NO}$ by amines. Especially the amines are considered important for the NO reduction in the freeboard region of the SFB boiler. ${ }^{15}$

In most work involving models and experiments on the reactions of the volatile nitrogen in fluidized beds, it is simply assumed that the volatile nitrogen is released as ammonia $\left(\mathrm{NH}_{3}\right)$ or amines $\left(\mathrm{NH}_{i}\right)$ in spite of the fact that no measurements of either $\mathrm{NH}_{3}$ or $\mathrm{HCN}$ concentrations have been published for fluidized beds so far. However, the result shown in Figure 9 is strong proof of the relevance of the assumption that $\mathrm{NH}_{3}$ is the dominating volatile

(13) Johnsson, J.-E. "Kinetics of Heterogeneous NO. Reactions at FBC Conditions". Rep. No. 9003, Department of Chemical Engineering. The Technical University of Denmark, 1990

(14) Walsh, P. M.; Chaung, T. Z.; Dutta, A.; Beér, J. M.; Sarofim, A. F. Proceedings of the Nineteenth Symposium (International) on Combustion: The Combustion Institute: Pittsburgh, 1982; $\mathrm{p} 1281$.

(15) Hampartsoumian, E.; Gibbs, B. M. J. Inst. Energy 1984, 57, 402.

(16) Wittler, W.; Schütte, K.; Rotzoll, G.; Schügerl, K. Chem. Ing. Tech. 1988, 60, 420 .

(17) Hirama, T.; Tomita, M.; Horio, M.; Chiba, T.; Kobayashi, M. Fourth Int. Conf. Fluidization, Kashikojima, Jpn. 1983. nitrogen species. Further support of the dominance of $\mathrm{NH}_{3}$ under fluidized-bed conditions is found in the literature ${ }^{18,19}$ and is discussed by Amand et al. ${ }^{8}$

The concentration of $\mathrm{NH}_{3}$ in the freeboard of a stationary fluidized bed test facility has been measured by Hirama and co-workers. ${ }^{17}$ They found that the $\mathrm{NH}_{3}$ level just above the bed varied greatly with the primary to secondary air ratio. The largest $\mathrm{NH}_{3}$ concentrations together with the lowest $\mathrm{NO}$ emissions were measured for a primary air stoichiometry of 0.75 . This result was taken as a proof of the importance of the volatile nitrogen species for the reduction of $\mathrm{NO}$ in stationary fluidized bed boilers.

In the case of the 12-MW CFB boiler, the $\mathrm{NH}_{3}$ disappears long before the NO reduction is completed. As a matter of fact, the $\mathrm{NH}_{3}$ disappears faster than the hydrocarbons which were produced at the same time. This can be seen by comparing the $\mathrm{NH}_{3}$ profile in Figure 9 with the profiles of $C_{1}$ to $C_{3}$ in Figure 8 . The fast disappearance of the $\mathrm{NH}_{3}$ in the combustion chamber can be explained as an effect of the oxidation of ammonia on char particles to either $\mathrm{N}_{2}$ or NO. This result is in accordance with measurements carried out by Hirama and co-workers in a small-scale CFB test rig. ${ }^{20}$ They measured only above the secondary air inlet and there they found the same low levels of $\mathrm{NH}_{3}$ as those shown in Figure 9 . Evidence of the oxidation of ammonia can be found in experimental results of refs 13 and 17 as well as in results of modeling calculations of NO formation in the 8-MW CFB boiler. ${ }^{7}$ Also, the NO peaks obtained during the devolatilization period when sufficiently large batches of fuel were dropped into the combustion chambers are in agreement with the fast conversion of the $\mathrm{NH}_{3}$ measured in the 12-MW CFB boiler.

The gas concentration profiles and the fuel batch test series in the two boilers are two independent proofs of the fact that ammonia does not contribute to the NO reduction in either of the CFB boilers.

\section{Conclusions}

The measurements reported here, together with the results of laboratory investigations previously published, make it possible to draw the following conclusions.

1. In circulating fluidized-bed boilers, the main part of the volatile nitrogen species is found as ammonia or amines.

2. The $\mathrm{NH}_{i}$ species produced from the volatiles are removed faster from the system than the $C_{1}$ to $C_{3}$ hydrocarbons.

3. In CFB boilers burning bituminous coal or other fuels of higher rank, the $\mathrm{NH}_{i}$ species do not contribute to the $\mathrm{NO}$ reduction, due to the fast oxidation to $\mathrm{N}_{2}$ or $\mathrm{NO}$ on char surfaces.

4. In CFB boilers burning bituminous coal, the $C O$ level in the combustion chamber is the key to the understanding of $\mathrm{NO}$ reduction in the boiler. The different $\mathrm{CO}$ levels in different CFB boilers, due to design and size of the boilers, can explain the NO reduction behavior seen under the burnout of batches of fuel which have been supplied to the boilers under normal operating conditions.

Acknowledgment. The experiments at the 8-MW CFB boiler were financially supported by the National Swedish

(18) Möller, P. Verteilung von Stickstoffverbindungen bei der Pyrolyse von Steinkohlen unter Bedingungen der Wirbelschichtfeuerung. Dissertation, University of Essen, 1989.

(19) Baumann, H.; Möller, P. Erdöl Kohle, Erdgas, Petrochem. 1990, 44,29 .

(20) Hirama, T.; Takeuchi, H. Ninth International Conference on Fluidized Bed Combustion; Mustonen, J. P., Ed.; The American Society of Mechanical Engineers: New York, 1987; p 848. 
Energy Administration and Götaverken Energy. The tests at the 12-MW CFB boiler were supported by the Energy Administration alone. The contributions to the experimental work made by the operating staff of each boiler, together with personnel from both Götaverken Energy and the Department of Energy Conversion, are gratefully acknowledged.

Registry No. NO, 10102-43-9; $\mathrm{CO}, 630-08-0 ; \mathrm{CH}_{4}, 74-82-8$; $\mathrm{NH}_{3}, 7664-41-7$; $\mathrm{HCN}, 74-90-8$.

\title{
Formation of $\mathrm{N}_{2} \mathrm{O}$ in Circulating Fluidized Bed Boilers
}

\author{
L-E. Ámand,* B. Leckner, and S. Andersson \\ Department of Energy Conversion, Chalmers University of Technology, S-412 96 Göteborg, \\ Sweden
}

Received May 8, 1991. Revised Manuscript Received July 29, 1991

\begin{abstract}
The $\mathrm{N}_{2} \mathrm{O}$ formation in circulating fluidized bed boilers is assumed to be influenced by two formation routes, either by char or by hydrogen cyanide originating from the fuel volatiles. A test program was carried out with the purpose of better understanding the formation routes. The test program consisted of step response tests in a 12-MW circulating fluidized bed boiler. Concentration profiles of $\mathrm{O}_{2}, \mathrm{CO}_{2}, \mathrm{CO}, \mathrm{NO}, \mathrm{HCN}, \mathrm{NH}_{3}$, and $\mathrm{C}_{1}$ to $\mathrm{C}_{3}$ hydrocarbons in the combustion chamber of the boiler were also measured in order to support the conclusions of the step response tests. The importance of the two routes is discussed, but no definite conclusions can be drawn about their magnitude.
\end{abstract}

\section{Introduction}

One of the advantages of fluidized bed combustion (FBC) is the low emissions of $\mathrm{NO}$ and $\mathrm{SO}_{2}$, a consequence of the combustion temperatures of $800-900^{\circ} \mathrm{C}$ which are low in comparison with the temperatures of flame combustion, $1000-1600^{\circ} \mathrm{C}$. The low temperatures in FBC prevent thermal NO formation and promote NO-reducing reactions during the combustion process. The temperature range is also suitable for sulfur capture by limestone addition.

The circulating type of FB boiler (CFB boiler) takes even better advantage of these properties ${ }^{1}$ and interest has gradually been focused on this type of boiler. However, the advantage of the lower emissions of $\mathrm{NO}$ and $\mathrm{SO}_{2}$ has lately been found to be offset by high emissions of $\mathrm{N}_{2} \mathrm{O}$ from FB boilers, ${ }^{2}$ although not from other combustion equipment. ${ }^{3} \quad \mathrm{~N}_{2} \mathrm{O}$ is one of the greenhouse gases, and $\mathrm{N}_{2} \mathrm{O}$ contributes also to ozone depletion in the stratosphere. ${ }^{4,5}$

The present work is a continuation of a project, previously published in refs 2 and 6 . Characterizations of NO and $\mathrm{N}_{2} \mathrm{O}$ have been carried out simultaneously but, for convenience, results of the present work which are related to NO are reported separately. ${ }^{7}$

The $\mathrm{N}_{2} \mathrm{O}$ emission has been found to depend on the bed temperature. A higher temperature leads to lower emis-

(1) Leckner, B.; Ámand, L-E. in Ninth International Conference on Fluidizing Bed Combustion; Mustonen, J. P., The American Society of Mechanical Engineers: New York, 1987; p 891.

(2) Amand, L-E.; Andersson, S. In Tenth International Conference on Fluidized Bed Combustion; Manaker, A. M., Ed.; The American Society of Mechanical Engineers: New York, 1989; $p 49$.

(3) Linak, W. P.; McSorley, J. A.; Hall, R. E.; Ryan, J. V.; Srivastava,

R. K.; Wendt, J. O. L.; Mereb, J. B. J. Geophys. Res. 1990, 95, 7533

(4) Ramanathan, V.; Cicerone, J. R.; Singh, H. H.; Kiel, J. T. J. Geophys. Res. 1985, 90, 5547.

(5) Crutzen, P. J.; Howard, C. J. Pure Appl. Geophys. 1978, 116, 497.

(6) Amand, L-E.; Leckner, B. Combust. Flame 1991, 84, 181.

(7) Amand, L-E.; Leckner, B. Oxidation of Volatile Nitrogen Compounds during Combustion in Circulating Fluidized Bed Boilers. Energy Fuels, preceding paper in this issue. sions of $\mathrm{N}_{2} \mathrm{O}$, which is the reverse of the bed temperature dependence of NO. In ref 2 it was discussed if the $\mathrm{N}_{2} \mathrm{O}$ formation from volatile nitrogen species (especially $\mathrm{HCN}$ ) or the heterogeneous reactions on char surface play an active role for the $\mathrm{N}_{2} \mathrm{O}$ formation. No definite answer to this question could be given. In ref 6 it was reported that the char loading of the boiler influenced the fuel-nitrogen conversion to $\mathrm{N}_{2} \mathrm{O}$. This could be seen by comparing $\mathrm{N}_{2} \mathrm{O}$ emission results from tests in which three kinds of fuel of different volatile contents were used. The temperature dependence of $\mathrm{N}_{2} \mathrm{O}$ was shown to include not only the bed temperature at the bottom, but the entire combustion chamber. Finally, the dependence of oxygen concentration of the $\mathrm{N}_{2} \mathrm{O}$ emission was evaluated.

It was shown by Leckner et al. ${ }^{8}$ that the decomposition of $\mathrm{N}_{2} \mathrm{O}$ in the cyclone depends upon the temperature level. An increase of the cyclone temperature by fuel gas injection leads to a substantial reduction of the $\mathrm{N}_{2} \mathrm{O}$ produced in the combustion chamber.

The present work is focused on the formation of $\mathrm{N}_{2} \mathrm{O}$ in the combustion chamber. Results from measurements in a 12-MW commercial-type CFB boiler are presented. These measurements include transient response tests in which there were changes of the fly ash recirculation and fuel feed rates. Gas concentration profiles of $\mathrm{O}_{2}, \mathrm{CO}_{2}, \mathrm{CO}$, $\mathrm{NH}_{3}, \mathrm{HCN}$, NO, and $\mathrm{C}_{1}$ to $\mathrm{C}_{3}$ hydrocarbons are also measured. The aim of the work is to continue the discussion of the importance of formation of $\mathrm{N}_{2} \mathrm{O}$ from the nitrogen-containing volatiles (e.g., $\mathrm{HCN}$ ) as compared with the formation related to char.

\section{Formation and Destruction of $\mathrm{N}_{\mathbf{2}} \mathrm{O}$}

The formation and destruction of $\mathrm{N}_{2} \mathrm{O}$ under fluidized bed conditions are not well understood. For gas flames, where the chemical reactions are homogeneous, there are

(8) Leckner, B.; Gustavsson, L. $\mathrm{N}_{2} \mathrm{O}$ reduction with Gas Injection in Circulating Fluidized Bed Boilers. J. Inst. Energy, in press. 